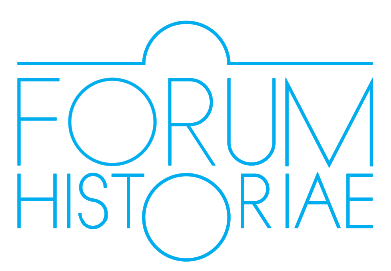

\title{
Skončilo sa vystúpenie (Francúzska) z prvej svetovej vojny?
}

\author{
Stéphane Audoin-Rouzeau
}

\begin{abstract}
:
AUDOIN-ROUZEAU, Stéphane: Is the Exiting (by France), from World War I, Over Yet?

To start, the author asks a thought-provoking question - whether France has definitively exited World War I. He defends the methodological approach to exiting the war, which may better render the complexities of the reconciliation of the war experience than the oft-used term the post-war period. He deals with the different amounts of time taken, and especially the persisting grief from the loss of loved ones which carries over into the later generations and in such a way the Great War still seems to be relevant even today. He links the renewal of interest in the memory of the Great War in the 1990s with the end of the Cold War, which he considers to be the final expression of World War I. The revival of interest in the memory of the Great War can be seen particularly in regard to the centenary, although at this point it is still too early to assess its impact.
\end{abstract}

Keywords: exiting wars, France, World War I, historiography, grief and trauma

$\mathrm{N}$ ázov tohto príspevku môže oprávnene provokovat: otázka, či po sto rokoch už prebehlo definitívne vystúpenie z prvej svetovej vojny, pôsobí ako zjavná chronologická absurdita. Okrem toho je evidentné, že jasná odpoved' na takú otázku nie je možná. Jej význam však spočíva v tom, že núti nanovo sa zamysliet' nad pojmom vystúpenie z vojny v súvislosti s prvou svetovou vojnou.

A dovolím si povedat', že to platí špeciálne v prípade „francúzskej“ Vel'kej vojny. Vieme totiž, že Francúzsko bolo z vel'mocí, ktoré viedli vojnu, postihnuté najviac, takže sú oprávnené odhady, že na konci konfliktu mali až dve tretiny francúzskeho obyvatel'stva nejaký dôvod na smútok. V tomto smere predstavovala Vel'ká vojna pre Francúzsko rozhodujúcu konfrontáciu s bezprecedentným masovým umieraním, s akým sa už nikdy neskôr nestretlo; išlo o násilnú, vzdialenú smrt’ bez možnej prítomnosti blízkych; smrt' bez tiel, ktoré by rodiny mohli pochovat'. A predsa mala takáto smrt' v čase samotnej vojny zmysel - hlboký patriotický význam vojny totiž vo francúzskej spoločnosti v rokoch 1914 až 1918 vyvoláva len málo pochybností - no následne sa tento zmysel v 20. a ešte viac v 30. rokoch 20. storočia ukazoval byt' stále menej pochopitel'ný. Ako vieme, po všeobecnej akceptácii vojny v danej chvíli nasledovalo rovnako hromadné odmietanie tej istej vojny po jej ukončení.

Tieto aspekty, o ktorých sa vel’a napísalo na iných miestach, zdôrazňujem z toho dôvodu, že podla môjho názoru doslova predurčujú otázku procesu francúzskeho vystúpenia z vojny v jeho celom (t. j. dlhom) trvaní a tiež v jeho 
zložitosti; zároveň pritom vyjadrujú relatívnu nemožnost' zavŕšenia procesu vystúpenia z vojny, a to možno až do súčasnosti.

V súvislosti s objektom nášho záujmu - „vystúpením“ z prvej svetovej vojny sa ukazuje byt' komplikované práve to, že „subjekt sa nachádza v subjekte“, ak to tak môžem povedat'. Lebo samotný pojem „vystúpenie z vojny“ je neoddelitel'ný od historiografického obratu, ktorý nabral „objekt Vel’ká vojna“ v 90. rokoch minulého storočia, a to najmä vo Francúzsku. Samotný zrod pojmu je teda neoddelitel'ný od konkrétneho kontextu..., a to od kontextu iného „vystúpenia z vojny“, poznamenaného pádom Berlínskeho múru koncom studenej vojny a sovietskeho impéria, posledného prejavu Vel'kej vojny. Vystúpenie z vojny je rovnako neoddelitel'né od oživenia pamäti prvej svetovej vojny, historickej spomienky na prvý celosvetový konflikt v Európe, ktoré sú pre Francúzsko obzvlášt' príznačné v porovnaní s inými európskymi krajinami. Ako teda oddelit' samotný pojem vystúpenia z vojny od tejto kontextovej hlušiny, ktorá ho istým spôsobom tak tesne spútava?

Otázka je o to citlivejšia, že historiografia Vel'kej vojny, ktorú tu obhajujem budem hovorit’ o tej, ktorá sa vykryštalizovala okolo výskumného centra Historial de Péronne ${ }^{1}$ od začiatku 90. rokov - sa podl'a môjho názoru vel'mi usilovala zakorenit’ samotný pojem „vystúpenie z vojny“ do historiografie. Vel'ká vojna dala tomuto konceptu charakter paradigmy $\mathrm{v}$ dôsledku zložitosti, bohatosti, dížky a často aj dramatickej povahy procesu, ktorý sa po roku 1918 začal v krajinách, ktoré predtým viedli vojnu.

Ked' sme v roku 2008 s Christophom Prochassonom vydali kolektívne dielo Vystúpit' z Vel'kej vojny. Svet a obdobie po roku $1918,{ }^{2}$ hned' na začiatku sme zdôraznili, do akej miery sa ritualizácia prechodu od vojny k mieru usilovala presadit' myšlienku jasného (ak nie brutálneho) a v každom prípade definitívneho konca obrovského konfliktu. Na niektorých miestach prebiehala skutočná mimézis návratu vojnového stavu, ako zdôraznil Bruno Cabanes, ${ }^{3}$ ked' analyzoval návrat francúzskych plukov zo železničných staníc v roku 1919, pri ktorom vojaci išli tými istými trasami ako o pät' rokov skôr - ako keby išlo o vojakov z leta 1914, ktorí sa v roku 1919 vracajú domov! Historická veda sa rovnako usilovala stanovit’ definitívny koniec konfliktu, ktorý sa práve zavŕšil, o čom svedčia tieto riadky historika Pierra Carona uverejnené v roku $1921 \mathrm{v}$ periodiku Revue de synthèse: „Musíme vychádzat’ z toho, že Versailleskou zmluvou sa skončila vojna rokov 1914 - 1918, tak ako sa Viedenskými zmluvami uzatvorili vojny revolúcie a cisárstva. Nie je dôležité, či považujeme za termín ukončenia dátum podpisu zmluvy alebo dátum jej vstupu do platnosti, alebo dátum ofi-

1 Historial de la Grande Guerre bol otvorený v roku 1992 a samotný názov je spojenie dvoch slov histoire (história) a mémorial (pamätník). Medzinárodný tím historikov z Francúzska, Vel'kej Británie a Nemecka poskytol v expozícii múzea nový pohl'ad na prvú svetovú vojnu, ked' sa sústredil na každodennost' vojakov bez ohladu na ich národnost'. Táto inštitúcia je zároveň múzeom a aj výskumným ústavom - poznámka editora. 2 AUDOIN-ROUZEAU, Stéphane - PROCHASSON, Christophe (ed.) Sortir de la Grande Guerre. Le monde et l'après-1918. Paris : Tallandier.

3 CABANES, Bruno. La Victoire endeuillée : la sortie de guerre des soldats français, 1918 - 1920. Paris : Seuil, 2004. 
ciálneho pokoja zbraní vo Francúzsku: rozdiel je len niekol'ko týždňov či niekol'ko mesiacov. Podstatné je to, že ked'sa už raz míl'nik stanoví, treba ho rešpektovat'; inak by sme smerovali $k$ zmätku a $v$ dôsledku zveličovania aj $k$ bezvýchodiskovej situácii.“4 Práve k tomuto (podla môjho názoru nevyhnutnému) „zmätku“, ak už nie k zveličovaniu a bezvýchodiskovej situácii, nás má priviest' pojem vystúpenie z vojny.

V tom istom kolektívnom diele, ktoré som už spomenul, sme na druhej strane zdôraznili úlohu, ktorú zohral pád Berlínskeho múru 9. novembra 1989 vo vnímaní toho, že druhá svetová vojna je konečne ukončená: „Povojnové obdobie... trvalo vel'mi dlho, no konečne sa chýli ku koncu," napísal v tejto súvislosti Tony Judt. $^{5}$ Čo však je „povojnové obdobie“? Na konci „krátkeho dvadsiateho storočia“ sme jasne pochopili, že pojem „povojnové obdobie“ sám osebe nepostačuje na vyjadrenie toho, čo bolo v hre v Európe po roku 1918; odvtedy sa vel'mi rozšíril pojem „vystúpenie z vojny“.

Čo sme tým heuristicky získali? Pojem bezpochyby umožňuje premýšlat' v dlhšom časovom horizonte bez klúčových dátumov, ktorými sú podpisy prímerí a neskôr mierových zmlúv: transformuje teda chronologický segment, ktorý je nevyhnutne pomerne krátky, na omnoho dlhší proces; vnáša tiež novú komplexnost' do analýzy možného pokračovania vel'kého vojnového násilia; a napokon má plasticitu, ktorej sa nič nevyrovná a vd'aka ktorej je možné urobit’ zo zrodu bol'ševického, fašistického a nacistického totalitarizmu rovnaký počet pokračujúcich vojen, ktorých politické pole sa posúva, pričom vonkajší nepriatel' sa mení na iného nepriatel'a, ktorý je teraz definovaný vnútri samotného národa. Práve týmto spôsobom nadobúda plný význam pojem „brutalizácia európskych spoločností", s ktorým tak sugestívne pracoval George Mosse.

$\mathrm{Na}$ tomto mieste by som sa chcel vyjadrit’ aj k pojmu čas. Vojna sa totiž neodohráva $v$ jedinom lineárnom čase, ktorý má podobu jednoduchého chronologického vektora. Vel'ká vojna si vytvorila vlastný čas, ktorý nemožno zjednodušit' na čas mieru, vytvorila skrátka špecifický čas, ktorý ako taký prežívali sociálni aktéri - čiže „subjektivizovaný“ čas. O Vel'kej vojne teda nemôžeme hovorit' bez toho, aby sme sa zaoberali jej vlastnou časovostou. A z pojmu „vystúpenie z vojny“ vyplýva práve jedna vel'ká otázka, a to otázka prechodu z tohto „iného" času vojny do odlišného času, času po vojne: teda času vystúpenia z vojny - a tento pojem by sa mal zrejme používat' v množnom čísle, lebo aj v jedinej krajine všetko nasvedčuje tomu, že takéto vystúpenie z vojny bolo viacnásobné alebo malo viacero podôb. Lepšie by teda asi bolo hovorit’ o vystúpeniach z vojny v množnom čísle, lebo v rámci „iného“ času samotnej vojny sa prekrývali rozličné časy. Ked’že nie všetci súčasníci vojny „bývali“ v tej istej časovosti, tieto odlišné časy sa premiešali, spolunažívali, občas si protirečili. A niekedy sa predížili aj po pokoji zbraní.

4 CARON, Pierre. Sur l'étude de l'histoire de la guerre. In Revue de synthèse historique, august - december 1921, s. 7-8.

5 JUDT, Tony. Après-guerre : une histoire de l'Europe depuis 1945. Paris : A. Colin, 2007, s. 24. Vyšlo pod názvom Povojnová Európa: história po roku 1945 v slovenskom preklade v roku 2007 vo vydavatel'stve Slovart. 
Jeden z najzaujímavejších z týchto mnohých časov sa špeciálne viaže k našej téme: je to čas smútku a psychického utrpenia spôsobeného masovým umieraním a jeho špecifickými podobami v rokoch 1914 - 1918. To, že historiografia Vel'kej vojny si stále viac uvedomovala dôležitost' smútku, híbku traumy tých, čo žijú, dlhé trvanie tohto smútku a ich pretrvanie aj v nasledujúcich generáciách, vel'mi prispelo k zakoreneniu pojmu vystúpenie $\mathrm{z}$ vojny $\mathrm{v}$ našom novom ponímaní konfliktu. Stále väčšie uvedomovanie si toho, že psychické utrpenie spôsobené masovým umieraním a násilím (v priemere okolo 1000 mŕtvych denne vo Francúzsku počas štyri a pol roka!) odznieva vel'mi pomaly - práve to z historiografického hl'adiska „transformovalo“ niekdajšie „povojnové obdobie“ na dnešné „vystúpenie z vojny“.

Teda vojnový smútok. Smútok a trauma a ich odovzdávanie: vojna sa totiž odovzdáva práve prostredníctvom nich v istej medzigeneračnej migrácii, ktorej prejavy dnes vedy o psyché poznajú lepšie. Extrémne by som to zhrnul takto: prvá generácia prežije vojnovú udalost', ale vlastne mlčí o tých najdôležitejších veciach; druhá musí žit' v mlčaní svojich predkov; tretia kladie otázky a môže o týchto témach konečne prehovorit'. Ako historik patriaci do tejto tretej generácie sa domnievam, že som taký proces zažil vo svojom vnútri v priebehu 90. rokov. Myslím si, že v roku 2013 som prostredníctvom osobného príbehu ${ }^{6}$ napokon pochopil, že som nebol len jeho svedkom, ale nevedomky a dlhodobo aj jeho účastníkom. Pocítil som účinky straty alebo rôzne možné podoby „straty“ v troch generáciách.

Práve takto Vel'ká vojna, ktorá sa v priebehu 70. a 80. rokov 20. storočia dostávala medzi „mŕtve udalosti“, v 90. rokoch znova „ožila“ a bolo možné klást” nové otázky o období po roku 1918. A tento návrat rokov 1914 - 1918 nebol len krátkodobý: trval celé štvrt'storočie až po súčasnú storočnicu. Tento proces „návratu“ udalostí z rokov 1914 - 1918 sme mohli sledovat' od roku 1998 vd'aka mimoriadnemu prieskumu verejnej mienky o historickom spomínaní Francúzov. V novembri 1998 totiž prieskum agentúry Ipsos o „významných udalostiach a osobnostiach 20. storočia“" poskytol po prvý raz príležitost' presnejšie zmerat' tento fenomén spomienkovej „prítomnosti“. Vel'ká vojna obsadila štvrté miesto po druhej svetovej vojne, kríze v roku 1968 a páde komunizmu. Prvé prekvapenie: vojna 1914 - 1918 tak napriek svojej vzdialenosti v čase predbehla budovanie Európy, dekolonizáciu, ropné krízy, krízu v roku 1929, ruskú revolúciu v roku 1917 a iránsku revolúciu v roku 1979. Navyše, čím boli respondenti mladší, tým vyššiu priečku získavala Vel'ká vojna v hierarchii udalostí 20. storočia; tí najmladší (15 - 19 rokov) ju dokonca kládli na druhé miesto. Inými slovami, čím viac plynul čas, tým viac rástol relatívny význam „udalostí 1914 - 1918“, dá sa povedat', že o to viac Vel’ká vojna mladla. Tento prieskum z konca 90. rokov vel'mi dobre ukázal proces, ktorým sa Vel'ká vojna postupne vracala - a už sa celkom vrátila - do historickej pamäti Francúzov.

6 AUDOIN-ROUZEAU, Stéphane. Quelle Histoire. Un récit de filiation. Paris : Seuil, 2013.

7 Les personnalités et les événements marquants du XXe siècle. prieskum Ipsos Opinion, Le Monde/France 3/Festival du film d'histoire de Pessac, 9. november 1998. Prieskum bol uskutočnený 6. a 7. novembra 1998. 
Aktuálna storočnica je síce falošným dôkazom, no bezpochyby predstavuje príchod spomienkového fenoménu, ktorý sa začal už dávno pred ňou.

Vysvetlit' príčiny tohto návratu rozhodne nie je jednouché. Aj tentoraz treba mysliet' na kontext: pád Berlínskeho múru, rozpad ZSSR, vytvorenie novej mapy strednej Európy, ktorá je pravým opakom mapy vytvorenej „zmluvami z parížskeho predmestia" v rokoch 1919 - 1920; d'alej - a možno predovšetkým návrat vojny do bodu v Európe, v ktorom vznikla v roku 1914 (Balkán), a potom ten názov Sarajevo, ktorý sa opät' vyslovuje každý deň počas obliehania mesta v rokoch 1992 - 1995. Zavŕšenie "krátkeho 20. storočia“ (Eric Hobsbawm) ${ }^{8}$ ul'ahčilo spomienkový návrat $\mathrm{k}$ jeho počiatkom, čiže návrat $\mathrm{k}$ jeho (oneskorenému) začiatku v rokoch 1914 - 1918. V priebehu 90. rokov sa tak uzavrel nekonečne tragický kruh európskych dejín a vrátili sme sa na ich začiatok.

Ide však určite aj o niečo iné než o tento obrat poznačený novou geopolitickou konjunktúrou 90. rokov. V plnom rozsahu to vysvetluje literatúra, najmä Jean Rouaud so svojou príznačnou knihou Polia cti, ktorá získala Goncourtovu cenu $1990 .{ }^{9} \mathrm{~V}$ diele sa píše o tom, ako $\mathrm{v}$ jednej francúzskej rodine $\mathrm{v}$ 60. rokoch vychádza pomaly a postupne na povrch vojnový smútok „tetušky“ (teta rozprávačovho otca), ktorá v roku 1916 prišla vo vojne o svojho brata Josepha; počas svojich posledných dní si ho pletie s iným Josephom - jej synovcom, ktorý zomrel na zástavu srdca krátko predtým. Toto zamieňanie si dvoch Josephov odhaluje celej rodine dovtedy skrytý smútok a zároveň otvára „kryptu" vytvorenú prechodom vojnového násilia, ktoré zažili predkovia rozprávača. Obrovský úspech knihy bezpochyby dostatočne naznačuje, aký by mohol byt' neukončený smútok z Vel'kej vojny vo Francúzsku: je to smútok tretej generácie - generácie Jeana Rouauda, rovnako ako aj autora týchto riadkov, teda generácie, ktorá dozrela práve na konci 20. storočia.

Tento proces návratu Vel'kej vojny od 90. rokov vo Francúzsku nepochybne signalizuje neukončený smútok. Neukončený, lebo nikdy nebol úplne „naplnený“. Lebo ak sa vo Francúzsku nezavŕšilo vystúpenie z vojny, je to bezpochyby preto, že vel'ký konflikt sa úplne neskončil v dôsledku neukončeného smútku v období tesne po 1914 - 1918.

Ukázali to aj emócie, ktoré len pár rokov pred storočnicou Vel'kej vojny vyvolala u Francúzov smrt' posledného francúzskeho vojaka z 1. svetovej vojny, ktorým bol Lazare Ponticelli, a tiež ohlas vyvolaný jeho „štátnym pohrebom“ zo 17. marca 2008: odozva týchto udalostí jasne ukázala, že Vel'ká vojna a osobitne jej rozmer súvisiaci s veteránmi je stále mimoriadne živou udalostou v kolektívnej historickej pamäti Francúzov. Ani v tomto prípade však taká horlivost’ nebola samozrejmá: smrt’ posledných veteránov francúzsko-pruskej vojny

8 HOBSBAWM, Eric. The Age of Extremes. The Short Twentieth Century, 1914 - 1991. London : Michael Joseph, 1994. Vyšlo v češtine pod názvom Věk extrémů - Krátké dějiny 20. století 1914 - 1991 v roku 2010 vo vydavatel'stve Argo.

9 ROUAUD, Jean. Les champs d'honneur. Paríž : Editions de Minuit, 1990. Autor sa vracia ku genéze diela v knihe Un peu la guerre (La vie poétique, 3). Paris : Grasset, 2014. 
z roku 1870 si v 50. rokoch minulého storočia nikto nevšimol, rovnako ako predtým smrt' posledných vojakov Napoleonovej Vel'kej armády na konci 90. rokov 19. storočia.

Vysvetl’uje to aj spoločenský význam storočnice Vel'kej vojny vo Francúzsku od roku 2014: iste, jej úplná bilancia ešte zatial' nie je urobená (o to viac, že spomienkové podujatia sa ešte neskončili), no celý rad indikátorov svedčí o tom, že táto téma je trvalo schopná mobilizovat’ národ. Ak sa ukázal mobilizačný potenciál storočnice Vel’kej vojny vo Francúzsku, je to podl’a môjho názoru práve preto, že vystúpenie Francúzska z vojny sa ešte neskončilo; a neskončilo sa z dôvodu neukončitel'ného smútku.

Nie je v tomto smere príznačné, že najväčší pamätník storočnice bol postavený vo Francúzsku a inšpirovaný masovým smútkom? Ide o pamätník „Obruč pamäti“ na cintoríne Notre-Dame-de-Lorette, odhalený 11. novembra 2014, kde sú v abecednom poradí zapísané mená vojakov, ktorí padli na území regiónu Nord-Pas-de-Calais v rokoch 1914 - 1918 bez ohl'adu na ich národnost'. Tento pamätník predstavuje na vnútroštátnej i medzinárodnej úrovni doteraz najväčšiu pamätnú svätyňu v Európe a vo svete, ktorá bola zasvätená padlým v prvej svetovej vojne. Okrem toho ide o významnú inováciu - ak už nie o určitý antropologický zlom - v tradícii pripomínania Vel'kej vojny, a to vd’aka tomu, že do kovu je $\mathrm{v}$ abecednom poradí a bez rozlišovania národnosti zapísaných 580000 mien bojovníkov, ktorí tam padli v rokoch 1914 až 1918.

Na záver: kedy sa vystúpenie z vojny vo Francúzsku skutočne zavŕši? Doteraz si tam vojna 1914 - 1918 zachováva vel'mi osobitné postavenie „poslednej katastrofy“10 (Henry Rousso). Predstavuje základnú referenciu, ako okrem iného ukazuje výzva k „posvätnej jednote“11 po atentátoch z 13. novembra 2015 v Paríži - tento mýtus zjednoteného a zomknutého Francúzska zoči-voči agresii vtedy často nadobúdal podoby a formulácie používané už v lete 1914, ${ }^{12}$ čo potvrdzuje, že Vel'ká vojna bola sto rokov od svojho začiatku stále jedným z najúčinnejších nástrojov, ktoré mali francúzski politici k dispozícii, ked' sa usilovali o sprostredkovanie minulosti, ked’že nedokázali naznačit' zrozumitel'nú budúcnost'.

Ako som už povedal, Vel'ká vojna zaznamenala vo Francúzsku za posledné štvrt’storočie nebývalý návrat. Bude však „tretia generácia“ schopná „odkázat' toto dedičstvo" nasledujúcej - štvrtej, či dokonca piatej generácii? Inými slovami: v akom momente sa jasne ukáže nemožnost' sl'ubu „Nikdy na nich nezabudneme!", ktorý dal vojakom 1. svetovej vojny vtedajší prezident republiky na konci svojho prejavu na počest' Lazara Ponticelliho 17. marca 2008? Kedy sa ukáže, že taký sl'ub nemožno dodržat'? Ešte inak povedané: kedy prestane byt'

10 ROUSSO, Henry. La dernière catastrophe. L'histoire, le présent, le contemporain. Paris : Gallimard, 2012. 11 Výslovne ju požaduje premiér Manuel Valls 15. novembra 2015.

12 Odkazujem tu na svoj článok: L’après-13 novembre: naissance et mort d'une « culture de guerre »? In Vingtième Siècle. Revue d'histoire, apríl - jún 2017, č. 134, s. 11-19. 
Vel'ká vojna nositel'kou silných emócií, ktoré sú s ňou stále spojené, a prejde do vel'kého hrobu "mŕtvych udalostí" (samozrejme, mŕtvych nie pre úzky okruh odborníkov, ale pre väčšinu l'udí ako tol'ko vojen pred ňou)? V čase, ked' píšem tieto riadky, zjavne nie je možné nájst' odpoved' na túto otázku.

Z francúzštiny preložila Kornélia Ševčíková

\section{Cituj:}

AUDOIN-ROUZEAU, Stéphane. Skončilo sa vystúpenie (Francúzska) z prvej svetovej vojny? In Forum Historiae, 2018, roč. 12, č. 2, s. 43-49. ISSN 1337-6861.

$\cdots$

Stéphane Audoin-Rouzeau

École des Hautes Études en Sciences Sociales

105 Boulevard Raspail

75006 Paris

sar@ehess.fr 